\title{
The Impact of Foreign Direct Investment, Aid and Exports on Economic Growth in Vietnam
}

\author{
Cung Huu NGUYEN ${ }^{1}$
}

Received: August 01, 2020 Revised: September 06, 2020 Accepted: September 10, 2020

\begin{abstract}
Foreign factors play an important role in the socio-economic development of each country, in which foreign direct investment (FDI), foreign aid and exports of goods and services are always given top priority in undeveloped countries as well as developing countries. The purpose of this study is to examine the relationship between the various factors such as FDI, foreign aid, exports and economic growth in Vietnam. The empirical method employed secondary time-series data set during the period 1997-2018 to determine the impact of FDI, foreign aid and exports on economic growth in Vietnam by using a linear approach. For this study, data is collected from the World Bank and relevant agencies in Vietnam. An empirical model is built with a correlation and regression analysis between economic growth (GDP, current) and three independent variables (FDI, aid, exports of goods and services). The results show that the relationship between FDI (net inflows), aid, exports and GDP (current) has a positive effect at a 1\% significance level. Based on these findings, the article recommends that Vietnam continues to seek effective solutions to maintain high economic growth rates by attracting FDI inflows, official development assistance (ODA), and increasing exports of goods and services.
\end{abstract}

Keywords: Gross Domestic Product, Foreign Direct Investment, Foreign Aid, Exports

JEL Classification Code: F30, F35, F43, B17

\section{Introduction}

Economic growth reflects an increase or decrease in the size of the economy in each country between the current year and the previous year or the current period and the previous period, which is expressed in scale and growth. The increase or decrease is more or less showing the scale of growth, and the rapid or slow rise shows the growth rate. High and sustainable economic growth is considered an achievement and a central theme in many economies both in developed and developing countries (Chirwa \& Odhiambo, 2016). GDP growth rate indicates the size of the economy in the future (Nguyen, 2019). Economic growth is measured by

${ }^{1}$ First Author and Corresponding Author. Faculty of Business Management, Hanoi University of Industry, Vietnam [Postal Address: No. 298, Cau Dien Street, Bac Tu Liem District, Hanoi, Vietnam] Email: nguyenhuucung@haui.edu.vn

(C) Copyright: The Author(s)

This is an Open Access article distributed under the terms of the Creative Commons Attribution Non-Commercial License (https://creativecommons.org/licenses/by-nc/4.0/) which permits unrestricted non-commercial use, distribution, and reproduction in any medium, provided the original work is properly cited. two main indicators - absolute growth and annual growth rate or average growth rate over a period (in GDP terms). What is economic growth? According to The Investopedia (2020), economic growth is an increase in the production of economic goods and services, compared from one period of time to another. It can be measured in nominal or real (adjusted for inflation) terms. Traditionally, aggregate economic growth is measured in terms of gross national product (GNP) or gross domestic product (GDP), although alternative metrics are sometimes used. The Economics Online supposes that economic growth is a macro-economic concept that refers to a rise in real national income, sustained over two consecutive quarters of a year.

Another definition by The Intelligent Economist (2020) shows that economic growth of a country is the increase in the market value of the goods and services produced by an economy over time. What is Gross Domestic Product (GDP)? According to The Investopedia (2020)'s definition, GDP is the total monetary or market value of all the finished goods and services produced within a country's borders in a specific time period. The Economic Times (2020) posits that GDP is the final value of the goods and services produced within the geographic boundaries of a country during a 
specified period of time, normally a year. GDP growth rate is an important indicator of the economic performance of a country. Thus, no matter what the perspective, the above definitions of economic growth and GDP reflect the increase or decrease of absolute or relative growth of a country's economy over a certain period.

The history of economic development in each country shows that the choice of economic growth model depends on the government's perspective, natural climate, land, natural resources, human resources, sciences and technology, and others. In order not only to promote economic development, there must be the rapid increase of income, the improvement of the people's life without falling into the middle income trap, but also protection of the environment. The economic growth model is a way to organize the mobilization and use of input resources to ensure economic growth over the years at a reasonable rate. The broad-based economic growth model is characterized by an increase in production volume due to an increase in capital, labor and natural resources. The intensive economic growth model is essentially based on modern science and technology, an increase in the efficiency and quality of growth, associated with protecting the ecological environment and improving social welfare. How many factors affect economic growth? From the theoretical models of economic growth as well as the development reality in developed and developing countries, economists all acknowledge that the motivation of economic development is based on four factors of economic growth - human resources, natural resources, capital, and technology. The potential of these four factors is different between countries, and the coordination between them also results in corresponding results. However, in the long-run, capital is considered the first essential factor to ensure growth. Accordingly, poor countries escape with great difficulty from the "vicious cycle of poverty", meaning that low income leads to low savings, which leads to low investment, which leads to low growth, which leads to low income.

Over 30 years of economic innovation, Vietnam's economic growth model has been selecting based on natural resource exploitation, low and unskilled labor usage, mainly FDI projects with low quality as machining and assembly of products, ODA with support for development of social issues and rural infrastructure, and others. According to economic growth theories and reality in countries based on four main factors sustaining the motivation of economic growth, including human resources, natural resources, capital, and technology, Vietnam has two main motivations for economic growth - young labor force and abundant natural resources - that are combined with two motivations for foreign investors - capital and technology - to transform from an underdeveloped country into a developing one with low- middle income, high economic growth rates, many export markets through the signing of bilateral, and multilateral agreements. How does foreign capital affect economic growth?

The purpose of this paper is to quantify the impact of FDI, aid and exports on economic growth in Vietnam by using a time-series data set for the period 1995-2018. This is the author's first study to separate foreign factors affecting economic growth in Vietnam by employing a linear model through regression and correlation analysis. The author hopes that this research will make significant scientific contributions by providing empirical evidence on the role of FDI, aid and export on economic growth in Vietnam. Based on the recognition of the role of factors affecting economic growth in Vietnam, this study proposes several policy implications that could improve the efficiency in attracting FDI inflows, efficient use of aid, and export promotion.

\section{Literature Review}

The early stage of development corresponding to the low starting point, countries exploit available resources to achieve the expected growth rate. The available resources were discovered by economists and incorporated into economic theories such as human resources (mainly unskilled labor), natural resources (raw materials), capital (less) and technology (mainly craft). After many years, countries have adopted the broad-based economic growth model and achieved a high annual growth rate from an underdeveloped country to a developing one. The input resources of each country's economy have had a change in quality. This means that human resources gradually increases the proportion of skilled labor and decreases the proportion of unskilled labor, a combination of exploitation of natural resources and refined materials for production, a combination of domestic capital and foreign capital, and a gradual shift from craft technology to modern technology. When countries reach a certain threshold of socio-economic development and impact of technological development, the economic growth model will be changed with increasing quality of growth. How do the four factors of human resources, natural resources, capital, and technology affect economic growth in developed country as well as developing country?

Economic theory and practice in countries have demonstrated that FDI inflows play an important role for economic growth in the host countries through supplementing a portion of the capital to the total investment. FDI contributes technology, financial capital, management capacity, experts, refined materials and other elements to development investment in the host countries. Thereby, the impact of FDI inflows on economic growth is a positive sign, significant (strong or weak) or insignificant depending 
on FDI size or efficiency of using FDI. Athukorala (2003) employed a time-series data set for the years 1959-2002 to analyze the relationship between FDI and economic growth in Sri Lanka, the results show that there was no robust link between FDI and economic growth as expected initially. Karimi and Yusop (2009) find that there is no robust link between FDI and economic growth in a bi-directional causality and long-run relationship in Malaysia, meaning that the relationship between FDI and economic growth is an indirect effect. A research by Fambon (2013) employed a time-series data set for the years 1980-2008 by using the autoregressive distributive lag approach to cointegration. The article analyzed the impact of FDI and other factors on economic growth in Cameroon. The results show that the relationship between FDI and economic growth is positive and significant in the short and long terms.

Rahman (2014) employed a time-series data set for the years 1981-2010 in Pakistan by using a multiple regression technique; the results show that the relationship between FDI and economic growth has a positive and significant effect. Erum et al. (2016) show that FDI has a positive effect on economic growth. The results of an empirical research in Malaysia on the relationship between capital market and other factors on economic growth show that the effect of FDI on economic growth has a positive sign in the long run, but not in the short run (Ali \& Fei, 2016). Another empirical study in Pakistan on the relationship between FDI and economic growth using a time-series data set from 1991 to 2015 shows that FDI has a positive and significant effect on economic growth (Ali \& Hussain, 2017). In an empirical study in Tunisia on the short-term and long-term relationship between FDI and economic growth, Bouchoucha and Ali (2019) employed a times-series data set for the years from 1980 to 2015 using the ARDL (Autoregressive Lag Distribution) approach with results showing that the impact of FDI on economic growth is positive and significant in both the short-term and long-term. Nantharath and Kang (2019) researched the effects of FDI and other factors on economic growth of the Lao People's Democratic Republic during the period 1993-2015. The empirical results find that FDI and trade openness has a positive impact on economic growth, while human capital and institutional quality have a negative sign.

In Vietnam, there are many studies analyzing the relationship between FDI and economic growth, all of which show that FDI has a positive and significant effect on economic growth in different stages. There was a positive effect of FDI on economic growth in Vietnam (Nguyen \& Nguyen, 2007). Hoang et al. (2010) analyzed the relationship between FDI and economic growth in Vietnam's sixty-one provinces by using a panel data set for the years from 1995 to 2006; the empirical results show that FDI and economic growth have a positive and significant effect. Ha et al. (2017) used a time-series data set for the period 1990-2015 in Vietnam, the results find that the effect of FDI inflows to GDP growth has a positive sign. Nguyen (2019) analyzed the role of economic growth in attracting FDI inflows into Vietnam for the years 2003-2018; the results show that real GDP and FDI have a positive and significant effect at $1 \%$ significant level. Empirical method was employed on a secondary time-series data set during the period 1995-2018 to determine the impact of FDI (net inflows) and other factors on economic growth in Vietnam by using a linear approach, the results show that the impact of FDI (net inflows) on economic growth has a positive sign and strongest at $1 \%$ significance level (Nguyen, 2020).

In order to escape the vicious cycle of poverty and become a developing country with middle-income level, underdeveloped countries with little initial capital accumulation, need to receive foreign aid such as humanitarian aid, non-refundable ODA, refundable ODA with low-interest or non-interest rates. Foreign aid is an additional financial source for any country's development investment, and its effect on economic growth is strong or weak depending on the use efficiency or size of ODA. The research results by Hadjimichael et al. (1995) show that the impact of foreign aid has a positive sign on economic growth over the period 1986-1992. A study on the impact of foreign capital inflows on economic growth in Pakistan during the period 1975-2004 finds that the relationship between foreign aid and economic growth is positive and significant.

Similarly, Mowlaei (2018) studied the impact of different forms of foreign capital inflows, namely, FDI, personal remittances and ODA on economic growth of 26 African countries, the results show that ODA and two other factors have a positive and significant effect on economic growth in the long and short run. Another study on the impact of foreign capital inflows on economic growth in Cameroon for the period 1980-2008 show that foreign aid has a positive and insignificant impact on economic growth in both the short and long term (Fambon, 2013). The empirical results by Rehman and Ahmad (2016), who analyzed the impact of foreign capital inflows on the economic growth in 21 developing countries over the period 1990-2013 show that net ODA has a significantly negative impact on economic growth of developing countries. Similarly, a study on sources of economic growth in Zambia on the impact of these factors on economic growth was calculated in the short and long run, while only foreign aid has a negative impact on economic growth in the long run (Chirwa \& Odhiambo, 2016).

The endogenous growth theory has provided persuasive evidence for the proposition that an increase in exports as a percentage of GDP has a positive effect on economic growth (Romer, 1986; Lucas, 1988). Other studies have suggested 
that exports can potentially create growth-accelerating forces (Grossman \& Helpman, 1991; Rodrik, 1992). Lloyd et al. (2001) studied the link between aid, exports and growth in Ghana by using a time-series data, the results show that exports, aid and public investment have a positive effect on long-run growth. Morever, in the pre-1983 period, the impact of exports and public investment on short-run growth has a negative sign while aid has no significant impact. Fatemah and Qayyum (2018) have modeled the impact of exports on the economic growth of Pakistan during the period 19712016; the study has proved that exports are an important and significant determinant of economic growth. The study done by Nguyen et al. (2016) using a time-series data in the period 2000-2016 shows that the exports activities have a positive impact on the ability to maintain the economic growth in the long run in Vietnam. Nguyen (2020) examined the impact of exports and other factors on economic growth in Vietnam by using linear approach via a secondary time-series data set during the period 1995-2018, the empirical results find that FDI (net inflows), export of goods and services (\% of GDP), financial freedom index have a positive and significant impact on economic growth.

\section{Data and Model}

According to the literatures on economic growth, the equation for determining the country's output can be shown as follows:

$$
\mathrm{Y}=\mathrm{C}+\mathrm{I}+\mathrm{G}+\mathrm{NX}
$$

In which, $\mathrm{Y}$ is national output,

$\mathrm{C}=$ Consumption

$\mathrm{I}=$ Investment

$\mathrm{G}=$ Government spending

$\mathrm{NX}=$ Net exports $(\mathrm{EX}-\mathrm{IM})$

This article only considers the effect of factors representing foreign capital flows on economic growth in Vietnam, namely, the influence of FDI, foreign aid (ODA), and exports to output. An empirical study is used to determine the effect of FDI, foreign aid and exports of goods and services on economic growth in Vietnam. Within the scope of this article, the authors perform the regression and correlation analysis by using a linear model. To accomplish the purpose of the study, the authors employs a secondary time-series data set ranging from 1997 to 2018 collected from The World Bank. Ordinary Least Squire (OLS) with multiple variables was used to assess the relation between dependent and independent variables. Data are analyzed, explained and presented by using descriptive statistics, and inferential statistics such as regression and correlation. The regression results show that there is no serious problem of a model mismatch.

Figure 1 shows the relationship between five independent variables and one dependent variable (see).

The relationship being tested is

$$
\begin{aligned}
& \mathrm{GDP}=\mathrm{F}(\mathrm{FDI}, \mathrm{AID}, \mathrm{EX}) \\
& \mathrm{FDI}=\beta_{0}+\beta_{1} \mathrm{FDI}+\beta_{2} \mathrm{AID}+\beta_{3} \mathrm{EX}+\varepsilon_{\mathrm{t}}
\end{aligned}
$$

With the given data, this article perform a linear regression on the relationship between three independent variables (foreign direct investment net inflows, net official development assistance and official aid received, exports of goods and services) and economic growth (real GDP) in Vietnam to analyze the role of each force on economic growth in Vietnam during the period 1997-2018, at the same time to compare the effect degree between factors on economic growth (see Table 1).

\section{Results and Discussion}

\subsection{Descriptive Statistics}

The descriptive statistics on the relationship between FDI, aid, export and economic growth in Vietnam are shown in Table 2. Output data shows that mean of real GDP reached USD104.7804 billion; maximum and minimum real GDP was USD244.9480 billion and USD26.84400 billion, respectively. It increased 9.1 times, average annual GDP growth rate was about 6\% over the period 1997-2018. Economic reforms since 1986 have been a big motivation to promote socio-economic development, quickly bringing Vietnam from one poorest country to a low-middle-income country in the world.

\begin{tabular}{|l|l|l|}
\hline Variables & & \\
\hline Foreign Direct Investment & $\begin{array}{c}\text { Economic Growth } \\
\text { GDP, current } \\
(1997-2018)\end{array}$ \\
\hline Foreign Aid & & \\
\hline Exports of Goods and Services & \\
\hline
\end{tabular}

Figure 1: The relationship between five independent variables and a dependent variable 
Table 1: Meaning of Variables

\begin{tabular}{|l|l|l|}
\hline Variables & \multicolumn{1}{|c|}{ Meaning } & \multicolumn{1}{c|}{ Unit } \\
\hline GDP & Gross domestic product & Current, Bill.US\$ \\
\hline FDI & Foreign direct investment, net inflows & BoP, current, Bill.US\$ \\
\hline AID & Net official development assistance & Current, Bill.US\$ \\
\hline EX & Exports of goods and services & Bill.US\$ \\
\hline$\varepsilon$ & Error variable & \\
\hline
\end{tabular}

Table 2: Descriptive Statistics

\begin{tabular}{|l|c|c|c|c|}
\hline & GDP & FDI & AID & EX \\
\hline Mean & 104.7804 & 6.204182 & 2.279318 & 85.74495 \\
\hline Maximum & 244.9480 & 15.50000 & 4.216000 & 259.5140 \\
\hline Minimum & 26.84400 & 1.298000 & 0.852000 & 11.57000 \\
\hline Std. Deviation & 73.05194 & 4.715962 & 1.065970 & 76.56992 \\
\hline Observations & 22 & 22 & 22 & 22 \\
\hline
\end{tabular}

Vietnam is a developing country that belongs to the group of countries with the highest growth rate in the world for many years now, owing to the contribution of foreign factors, namely, FDI, ODA and exports. Minimum of FDI (net inflows) was USD1.298 billion in 2000, due to the effect of the Asian financial crisis during the period 19971999, FDI inflows to Vietnam gradually decreased from USD2.22 billion in 1997 to USD1.298 billion in 2000, but starting from 2003 gradually recovered in attracting FDI and began to increase sharply from 2007 - about USD6.7 billion to 2018 about USD15.5 billion. The reason is that Vietnam became an official member of the World Trade Organization (WTO) in 2007; also, Vietnam signed and participated in a series of free trade agreements (FTA), and became a highly open economy.

Minimum of foreign aid (net official development assistance and official aid received) was USD0.852 billion in 1997 and gradually increased over the years. The cause of these achievements is that Vietnam has been performing relatively well in receiving and using foreign aid for many years, though there have been issues primarily related to bottlenecks in the implementation of key infrastructure projects rather than restrictions of capacity. In fact, the majority of ODA was spent on infrastructure development to restructure the economy through the application of modern production methods. However, since Vietnam became a low-middle-income country, ODA into Vietnam has been decreasing during the period 2014-2018, from USD4.216 billion in 2014 to USD1.633 billion in 2018, and is forecasted to continue to fall in the coming years. Besides, corruption in several places, even with projects implemented by reputable partners, has the consequence to reduce the effectiveness of development assistance in benefiting citizens.

Promoting exports is one of the driving forces of economic growth; Vietnam has been continuously promoting exploitation of traditional markets and expanding new markets. Up to now, Vietnam's export market for goods and services has been present in over 200 countries and territories. Important export markets such as the United States, the European Union (EU), Southeast Asian countries, Japan, South Korea, and China have experienced high export turnover growth in the past period, where China and South Korea are the two markets with the highest average growth rate, $21.7 \%$ and $21.5 \%$, respectively. As a result, annual average during the period 1997-2018 for the exports of goods and services reached approximately USD85.74495 billion - the lowest figure was USD11.57 billion in 1997 and the highest was USD259.514 billion in 2018 (World Bank Open Data). 
Table 3: Correlation Matrix between GDP and Independent Variables.

\begin{tabular}{|l|c|c|c|c|}
\hline & FDI & AID & EX & GDP \\
\hline FDI & 1 & & & \\
\hline AID & 0.611240 & 1 & 1 & \\
\hline EX & 0.948280 & 0.572545 & 0.988913 & 1 \\
\hline GDP & 0.960143 & 0.680339 & & \\
\hline
\end{tabular}

Table 4: Regression Analysis Results for GDP and Explanatory Variables.

\begin{tabular}{|l|c|c|c|c|}
\hline Variable & Coefficient & Std. Error & t-Statistic & Prob. \\
\hline C & 4.458885 & 1.548165 & 2.880109 & 0.0100 \\
\hline FDI & 1.779350 & 0.450778 & 3.947287 & 0.0009 \\
\hline Aid & 10.83698 & 0.772135 & 14.03509 & 0.0000 \\
\hline EX & 0.753177 & 0.026801 & 28.10271 & 0.0000 \\
\hline R-squared & 0.998570 & F-statistic & 4189.362 \\
\hline Durbin-Watson stat & 1.834989 & Prob(F-statistic) & & 0.000000 \\
\hline
\end{tabular}
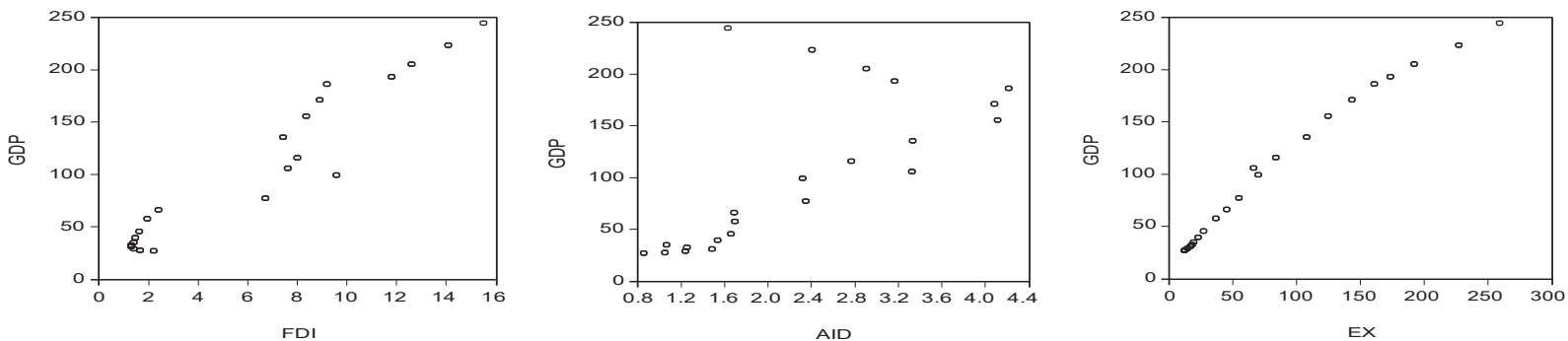

Figure 2: Residuals of Regression Analysis Results

\subsection{Correlation and Regression Analysis}

Table 3 shows the correlation analysis undertaken between real GDP and explanatory variables such as FDI, aid, and exports. The impact of factors on real GDP could be positive or negative. The correlation outputs show that there is a positive and significant sign between GDP and FDI, aid, and exports. Thus, FDI, aid and exports have really become important motivations for economic growth in Vietnam for many years.

Table 4 shows the regression results, which indicate that the model is consistent and statistically significant at a $1 \%$ significance level $(\operatorname{Prob}(\mathrm{F}$-statistic $)=0.000000)$. Sign of $\beta_{1}$, $\beta_{2}, \beta_{3}$ shows that there is a significant positive effect of three independent variables on a dependent variable. Sign of $\beta_{0}=$ 4.458885 shows that not only FDI, Aid, and exports affect economic growth, but also other factors that are the driving force for Vietnam's economic growth in the period 1997 2018. Further, R-squared $=0.998570$, the explanatory level of the determinants of real GDP in terms of $\mathrm{R}^{2}$ by $99.85 \%$.
This means that around $99.85 \%$ of variation in real GDP is explained by this model through independent variables such as FDI (net inflows), aid, and exports of goods and services. The value $d$ of Durbin-Watson test by $d=1.834989$ while at $5 \%$ level significance $(\alpha=5 \%=0.05)$, sample numbers $\mathrm{n}=22$, independent variables in the model $\mathrm{k}^{\prime}=3$, inferred $d L=1.053$ and $d U=1.664$. Due to $\mathrm{d}_{\mathrm{u}}=1.664<\mathrm{d}=$ $1.834989<4-\mathrm{d}_{\mathrm{u}}=2.336$, this concludes that the model has not an autocorrelation phenomena. To have a comparison of importance among factors, the author continues to analyze the regression results of each factor (see Figure 2).

\subsubsection{Foreign Direct Investment}

As analyzed above, empirical evidence previously studied in Vietnam and in other countries suggests that the relationship between FDI and economic growth is a positive sign. This means that attracting FDI inflows will add an important part of capital to total investment capital, an increase in employment and income, a motivation of exports 
for goods and services, increase labor productivity through technology transfer as well as management experiences and skills, and stimulate economic growth. In Vietnam, foreigninvested enterprises are the most dynamically-developing area with GDP growth rate consistently higher than the national growth rate. According to the statistical data shows, the contribution ratio of FDI enterprises to GDP has gradually increased from $2 \%$ in 1992 to $18.97 \%$ in 2011 and about $20 \%$ in 2018 . Besides, $\beta_{1}=1.779350$ and $p=0.0009$ show that the effect of FDI (net inflows) on economic growth has a positive sign and significant at a $1 \%$ level of significance. This value implies that in constant condition of other factors, FDI (net inflows) rises to USD 1 billion, an increase in real GDP is USD 1.779350 billion for the years 1997-2018. This result is consistent with the finding of Nguyen (2007), Hoang et al. (2010), Fambon (2013), Rahman (2014), Erum et al. (2016), Ali and Fei (2016), Ali and Hussain (2017), Ha et al. (2017), Nantharath and Kang (2019), Bouchoucha and Ali (2019), Nguyen (2019), Nguyen (2020). A positive and significant relationship between FDI and economic growth through empirical evidence reminds countries that the competitive pressures to attract FDI inflows is increasing. This is both a pressure and motivation for Vietnam's government to change its strategies to attract FDI inflows and foreign aid in the next period.

\subsubsection{Foreign Aid}

Official Development Assistance (ODA) is a form of foreign investment, with the advantages of low interest rates, long term, and a non-refundable portion of ODA. ODA flows mainly from the more developed countries to finance the less developed countries. Stemming from the benefits of ODA for the socio-economic development of a country like Vietnam, donor countries are often linked with binding conditions such as expanding cooperation, dominating new market, ensuring security-defense objectives as well as political goals, and others. However, the effects of ODA on economic growth are different between countries, possibly having strong or weak impact, positive or negative sign. This depends on the use of ODA by each country such as efficiency, transparency, compliance with commitments, no corruption, others. In Vietnam, the empirical results show that foreign aid has a strong positive and significant impact on economic growth in the long run at $1 \%$ significance level. $\mathrm{B}_{2}=10.83698$ implies that in constant condition of other factors, foreign aid (net official development assistance and official aid received) rises to USD1 billion, an increase in real GDP is USD10.83698 billion for the years 1997-2018. This result is consistent with the finding of Hadjimichael et al. (1995), Fambon (2013), Mowlaei (2018). Thus, Vietnam has been using foreign aid flows with high efficiency, and brought confidence to donor countries, as evidenced by the fact that Vietnam has been maintaining its reception of foreign aid for decades.

\subsubsection{Exports of Goods and Services}

As a low starting point, an underdeveloped country has many difficulties in exporting goods and services due to its low initial accumulation capital, predominant technology, poor management skills, and a mainly unskilled labor force. As a result, this country as a closed economy, limited international economic integration, poor export market, goods and services mainly supply to domestic market, small economy size, and low annual economic growth rates. Thus, there is a causal relationship between exports and economic growth. The export is found to be significant in determining economic growth and economic growth significantly affects exports (Singh, 2015). From an underdeveloped country to a developing country with low middle income or higher, countries need to have a long period of high annual economic growth, even in the group of countries with the highest growth rates. In doing so, countries not only exploit the domestic market but also expand the international markets through the signing of bilateral and multilateral trade agreements, as a result, the size of production is expanded to supply domestic and export market. To become a developing country with low middle income, Vietnam has had many open economic policies to attract FDI inflows, foreign aid and expand international markets. On the basis of the expansion of export market results in an increase in production size, which in turn has a positive effect on economic growth. The empirical results have also proved that a causal relationship between exports and economic growth has a strong positive and significant impact at $1 \%$ significance level during the period 1997-2018. B $\mathrm{B}_{3}=$ 0.753177 implies that in constant condition of other factors, exports rises to USD1 billion, an increase in real GDP is USD0.753177 billion for the years 1997-2018. This result is consistent with the finding by Romer (1986), Lucas (1988), Lloyd et al. (2001), Nguyen et al. (2016), Fatemah and Qayyum (2018), Nguyen (2020).

\section{Conclusion and Policy Implication}

The purpose of this paper is to analyze the effect of FDI, foreign aid, and exports on economic growth in Vietnam during the period 1997-2018. At the same time, the author compares the impact between factors on economic growth. The role of all three factors on economic growth is both strong at $1 \%$ significance level and a positive causal relationship. Based on the findings of this article, the author proposes several policy implications as follows.

Firstly, to have a new motivation in attracting FDI inflows and continue to be able to compete with other countries in the region, Vietnam needs to quickly shift from FDI projects 
using cheap labor and natural resources to high-tech projects through tax and land incentives, infrastructure development, administrative procedure reform, the complete elimination of informal fees, provision of high quality human resources, modern health care system, others.

Secondly, in order to achieve the goals of socio-economic development strategy in each period, Vietnam has always been seeking positive solutions to mobilize all sources of domestic and foreign capital, including state budget, private capital, and especially external investment capital (FDI, ODA, concessional loans, remittances, others). As Vietnam becomes a developing country with low middle income, the relationship between Vietnam and foreign donors will continue to fundamentally change, transiting from development aid relations to partnership. Although Vietnam continues to receive the active support of the international community, foreign donors are adjusting development cooperation policies with Vietnam towards gradual shift from providing ODA to loans with less favorable terms such as commercial loans, investment cooperation, and gradually terminating development assistance programs for Vietnam. Vietnam should consider selecting sectors for the use of loan capital on the basis of its financial conditions. For projects that directly promote economic growth associated with sustainable development, priority should be given to using ODA loans and foreign concessional loans, such as projects of transport infrastructure, smart cities, clean energy, smart agricultural development, or projects with spillover effects such as climate change adaptation, environmental quality improvement, education, health, technology, and skills. However, the selection of projects should be in the overall balance of medium-term public investment and mediumterm public debt, focusing on repayment duration to ensure credibility and responsibility for foreign donors.

Thirdly, stemming from the positive causal relationship between exports and economic growth in Vietnam in the period 1997-2018, Vietnam needs to continue promoting exports of goods and services with solutions as follows: strictly implementing commitments to bilateral and multilateral agreements, while continuing to sign new agreements with other countries and international economic organizations, thereby maintaining available export markets and expanding new export markets. Formulating policies to support enterprises to invest in the innovation of equipment, technology and production processes to meet the quality and standards of export markets. Restructuring export products in the direction of increasing the proportion of products with high added value. Strengthening market information to create favorable conditions for businesses to exploit export opportunities. Promoting the development of infrastructure and logistics services. Strengthening the simplification of administrative procedures, perfecting the management mechanisms and policies of import and export activities, and providing consultancy information and legal support to businesses related to import and export activities.

\section{References}

Ali, A., \& Fei, Y. S. (2016). Impact of Malaysia's Capital Market and Determinants on Economic Growth. Journal of Asian Finance, Economics and Business, 3(2), 5-11. https://doi. org/10.13106/jafeb.2016.vol3.no2.5.

Ali. N., \& Hussain, H. (2017). Impact of Foreign Direct Investment on the Economic Growth of Pakistan. American Journal of Economics, 7(4), 163-170. http://article.sapub. org/10.5923.j.economics.20170704.01.html

Athukorala, W. (2003). The Impact of Foreign Direct Investment for Economic Growth: A Case Study in Sri Lanka. In: 9th International Conference on Sri Lanka Studies, Full Paper Number 092, 28th - 30th November 2003.

Bouchoucha, N., \& Ali, W. (2019). The Impact of FDI on Economic Growth in Tunisia: An Estimate by the ARDL Approach. Munich Personal RePEc Archive Paper No. 91465. https:// mpra.ub.uni-muenchen.de/91465/2/MPRA_paper_91465.pdf

Chirwa, T. G., \& Odhiambo, N. M. (2016). Sources of Economic Growth in Zambia: An Empirical Investigation. Working Paper 05/2016. https://doi.org/10.1177/0972150916668449

Economicsonline. (2020). Economic growth. Retrieved August 10, 2020 from: https://www.economicsonline.co.uk/Definitions/ Growth.html

Economictimes. (2020). Economic growth. Retrieved August 10, 2020 from: https://economictimes.indiatimes.com/definition/ gross-domestic-product

Erum, N., Hussain, S., \& Yousaf, A. (2016). Foreign Direct Investment and Economic Growth in SAARC Countries. Journal of Asian Finance, Economics and Business, 3(4), 5766. https://doi.org/10.13106/jafeb.2016.vol3.no4.57

Fambon, S. (2013). Foreign Capital Inflow and Economic Growth in Cameroon. WIDER Working Paper No. 2013/124. Helsinki: UNU-WIDER. https://www.wider.unu.edu/sites/default/files/ WP2013-124.pdf

Fatemah, A., \& Qayyum, A. (2018). Modeling the Impact of Exports on the Economic Growth of Pakistan. Munich Personal RePEc Archive Paper No. 83929. https://mpra.ub.uni-muenchen. de/83929/1/MPRA_paper_83929.pdf

Grossman, G., \& Helpman, E. (1991). Innovation and Growth in the Global Economy. Cambridge, MA: MIT Press.

Ha, T. C., Wang, Y.Z., Hu, X. J., \& Than, T. S. (2017). The Impact of Foreign Direct Investment on Economic Growth: A Case Study in Vietnam 1990-2015. Industrial Engineering Letters, 7(4), 1-7. https://iiste.org/Journals/index.php/IEL/article/ view/37395

Hadjimichael, M. T., Ghura, D., Muhleisen, M., Nord, R., \& Ucer, E. M. (1995). Sub-Saharan Africa: Growth, Savings 
and Investment, 1986-93. IMF Occasional Paper No. 118, Washington, DC: International Monetary Fund.

Hoang, T. T., Wiboonchutikula, P., \& Tubtimtong, B. (2010). Does Foreign Direct Investment Promote Economic Growth in Vietnam? ASEAN Economic Bulletin, 27(3), 295-311. https:// www.jstor.org/stable/25773884

Intelligenteconomist. (2020). Economic growth. Retrieved August 10, 2020 from: https:/www.intelligenteconomist.com/ economic-growth/

Investopedia. (2020). Economic growth. Retrieved August 10, 2020 from: https://www.investopedia.com/terms/e/ economicgrowth.asp

Karimi, M. S., \& Yusop, Z. (2009), FDI and Economic Growth in Malaysia, Munich Personal RePEc Archive, MPRA Paper No. 14999. https://mpra.ub.uni-muenchen.de/14999/1/fdi_on_ economic_growth.pdf

Lloyd, T., Morrissey, O., \& Osei, R. (2001). Aid, Exports and Growth in Ghana. Nottingham: Centre for Research in Economic Development and International Trade, University of Nottingham. https://www.nottingham.ac.uk/credit/documents/ papers/01-01.pdf

Lucas, R. (1988). On the Mechanics of Economic Development. Journal of Monetary Economics, 22(1), 3-42. https://doi. org/10.1016/0304-3932(88)90168-7

Mowlaei, M. (2018). The Impact of Foreign Capital Inflows on Economic Growth on Selected African Countries. African Journal of Economic and Management Studies, 9(4), 523-536. https://doi.org/10.1108/ajems-01-2018-0021

Nantharath, P., \& Kang, E. (2019). The Effects of Foreign Direct Investment and Economic Absorptive Capabilities on the Economic Growth of the Lao People's Democratic Republic. Journal of Asian Finance, Economics and Business, 6(3), 151-162. https://doi.org/10.13106/jafeb.2019.vol6.no3.151
Nguyen, H. C. (2019). Gross domestic product and foreign direct investment: Empirical evidence from Vietnam. European Scientific Journal, 15(31), 38-51. https://doi.org/10.19044/ esj.2019.v15n31p38

Nguyen, H. C. (2020). Impact of Foreign Direct Investment on Economic Growth in Vietnam. Advances in Management \& Applied Economics, 10(2), 89-99. http://www.scienpress.com/ Upload/AMAE/Vol\%2010_2_6.pdf

Nguyen, M. H., Do, H. H., \& Nguyen, M. H. (2016). Analysing the Effects of the Exporting on Economic Growth in Vietnam. In: International Econometric Conference of Vietnam, Econometrics for Financial Applications (pp. 597-610). https:// link.springer.com/chapter/10.1007/978-3-319-73150-6_47

Nguyen, N. A., \& Nguyen, T. (2007). Foreign Direct Investment in Vietnam: An Overview and Analysis the Determinants of Spatial Distribution Across Provinces. MPRA Working Paper No. 1921. https://mpra.ub.uni-muenchen.de/1921/

Rahman, Z. U. (2014). Impact of Foreign Direct Investment on Economic Growth in Pakistan. Journal of Economics and Sustainable Development, 5(27), 251-255.

Rehman, S., \& Ahmad, H. K. (2016). The Impact of Foreign Capital Inflows on Economic Growth: Pooled Mean Group Analysis for Developing Countries. Pakistan Economic and Social Review, 54(2), 191-203. https://www.jstor.org/stable/26616706

Rodrik, D. (1992). Closing the Productivity Gap: Does Trade Liberalization Really Help? Oxford, UK: Clarendon Press.

Romer, M. (1986). Increasing Returns and Long-run Growth. Journal of Political Economy, 94(5), 1002-1037. https://www. jstor.org/stable/1833190

Singh, G. (2015). Causality Between Export and Economic Growth: A Cause Study of India. Indian Journal of Accounting, 47(1), 109-120, Available at SSRN: https://ssrn.com/ abstract $=2714774$ 